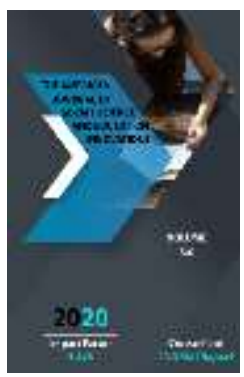

\title{
The Importance Of Social Psychological Research And Methods In Children's Lives
}

\author{
Musurmonkulova Nilufar Alisherovna \\ Termez Branch Of The Tspuniversity Named After Nizami, Uzbekistan
}

Journal Website: http://usajournalshub.c om/index,php/tajssei

\section{ABSTRACT}

This article reveals the relevance of psychological research in the study of the impact of siciopsychological research in the study of the impact of socio-psychological research and methodion human life and difficult life situations human life and difficult life situations. Theoretical analyses of such concepts asaition life situation life situation difficult life situation presents the classification of types of difficult life situations considered in the works of scentists.

\section{KEYWORDS}

Social sitations, life sitations, difficult life sitation, life adaption.

\section{INTRODUCTION}

Competition in the labor market, intensive development of information technologies, fundamental changes in the economic, political, socio-cultural spheres of society, globalization processes place high demands on the training of highly qualified personnel for all spheres of society. In these conditions, the issue of creating equal conditions and opportunities for participation in the life of the society, obtaining education for all its members: both physically and psychologically healthy, well-to-do individuals, and for those who are in a difficult life situation (DLS), namely, individuals with disabilities, 
disabilities, orphans, victims of domestic violence, etc., is relevant. The Government of Uzbekistan is carrying out targeted activities in this area.

\section{MATERIALAS AND METHODS}

Thus, in 2017, the President of the Republic of Uzbekistan, Sh. M. Mirziyoyev, issued Decree No. UP-5270 of 1 December 2017 on measures to radically improve the system of State support for persons with disabilities, according to which "the system of inclusive education and employment of persons with disabilities will be improved to ensure their involvement and active participation in the social and economic life of society"; "intensification of research in the area of State support for persons with disabilities...". On the basis of this document, persons with disabilities, starting from the 2018/2019 academic year, have the opportunity to enter higher education within the additional quota. Thanks to such support of the state, in the 2018/2019 academic year, 996 applicants with disabilities were admitted to the budget places in universities of Uzbekistan [43]. Such activity of the government is aimed, first of all, at ensuring the transition of a person in a difficult life situation from a consumer attitude to life, paternalistic attitudes to the state to an active, creative way of life. However, ensuring the effectiveness of the state's perspective decisions requires qualitative and comprehensive personal studies in the housing and utilities sector. A special place in this approach is occupied by psychological studies of students in the DLS. Despite a large number of studies dedicated to the study of university students both in Uzbekistan and abroad, students in DLS are a poorly researched group of students. Analysis of scientific sources has shown that social and psychological peculiarities of their coping behavior, adaptation, psychological well-being, meaningful orientations, social networks, etc. are not sufficiently studied.
Conducting research in this direction will help, in our view, to solve a number of sociopsychological, as well as economic issues a, it is necessary to have "in-depth knowledge of theory and theoretical reflection", which will create conditions for multilateral research of students in difficult life situations, requiring the development of psychodiagnostic methods for their study, special psychological and pedagogical assistance; practical psychological methods of influence in the course of the educational process, within the framework of the activities of the psychological assistance service of the university in such a way as to ensure social and psychological stability, well-being of students in the DLS, full Self-rehabilitation is expressed in the active conscious organization of self-help and its own constant readiness to come to the aid of others, the use of its unique situation for personal and creative growth, as well as social support in the conditions of interpersonal interaction and joint activities. On the basis of the analysis, it can be concluded that despite a large number of studies, the researchers approach the concept of "difficult life situation" is not unambiguous, there is a great deal of discrepancy in the understanding of the phenomenon in question. Some scientists are suitable in terms of temporal difficulties, others in terms of the degree of tension that arises at one point or another in life under the influence of severe shocks, hardships and difficult events. We agree with the opinion of S.P. Politova and N.I. Ismailova, who argue that "those who are in a difficult life situation all the time" remain outside the attention of scientists[28]. For example, disabled people from childhood who have lost their ability to work and have received disability of I - III groups, orphans, persons who experience domestic violence for a long time.

Due to the fact that it is this category of subjects that will be the subject of further research, summarizing the approaches to DLS, formulated such concepts as life 
situation, difficult life situation. Further on, we will proceed from such a position, in which, when it comes to the life situation, it should be understood "as a condition of human life" (T.D. Vasilenko)[12].

Thus, from our point of view, life situations are those that, as a condition of human life, are characterized by dynamism, multi-component, unlimited in time and space, determine the behavior of a person in different life circumstances at a particular period of the life cycle, affect the emotional, cognitive, behavioral, existential aspects of the psyche of a person, go beyond the limits of his life, including other people. Further research will also adhere to the Swedish Researchers G. Bernler and L. Yunsson's understanding of DLS, which describes it as "standing in a longterm difficult situation, which can be characterized as a chronic or permanent crisis" [4]. We believe that a difficult life situation should be studied as a long-term phenomenon from the point of view of the system approach, as it provides an opportunity to comprehensively study the situation, identify all the factors of violations and positive changes in the life of anindividual in relation to the inner world of the person and the external environment, which includes living conditions, relationships, significant people, social environment, etc. Thus, we believe that a difficult life situation can be defined as a condition of a person's life, as a longterm open system, in which the ability to meet their basic life needs, intentions, aspirations and values with the help of the experience formed in the previous period of life, cognitive, emotional, behavioral features of the human psyche due to limited possibilities of health, is violated or becomes impossible as a result of the influence of the environment or internal psychological conditions.

\section{RESULT, DISCUSION AND CONCLUSION}

In these life circumstances, in the absence of comprehensive development, as well as the formation of non-adaptive cognitive, emotional, behavioral characteristics of the human psyche is a long-term experience of difficulties that cause impairment of the ability or inability to meet their basic needs, intentions, aspirations and values in life. Therefore, when there are ample opportunities for higher education for people with disabilities, disabled people, orphans, etc., the study of their strategies of behavior in complex life situations, which are saturated with student life, their psychological features arean urgent task of psychological science in today's world. In the conditions of intensive development of technologies, economic crisis, rapid changes in the social and political life of the society, research could become promising directions in the study of students in a difficult life situation, as a special category of future specialists with a powerful potential, able not only to adapt to existing conditions, but also to be in the forefront of democratic development, innovative transformations not only in Uzbekistan, but also in the world, provided that the attitude of others towards them is built up correctly, it would be possible to study their coping behavior, peculiarities of psychological wellbeing, adaptation resources of the psyche, personal and subjective factors in their perception of the life situation as difficult, etc. The results of the research could serve to develop an effective model of psychological assistance service, organization of psychological, pedagogical, social and economic support depending on the needs of students in DLS, career centers in universities for such students, as well as to develop the scientific basis for training, retraining, professional development of specialists to work with students in DLS in the context of inclusive education, ensuring gender equality, prevention of all types harassment, violence, etc. 


\section{REFERENCES}

1. The Rights of the Child (Safeguards) Act. No. ZRU-139. of Tashkent, 7 January 2008, Narodnoye Slovo newspaper, 8 January 2008, No. 5 (4384).

2. Karamyan M. Kh. Psychology of health. Tashkent .: MUMTOZ SOZ, 2010.116p.

3. Karamyan M. Social-psychological Factors and Health RelatedBehaviour (an Empirical Study in Uzbekistan)'//In Environmental Protection of Urban and Suburban Settlements. Monograph. Novi Sad, 2005. pp. 125-131.

4. The Law of the Republic of Uzbekistan "On the Protection of Women from Harassment and Violence". http://lex.uz/docs/4494712

5. The Act "On guarantees of equal rights and opportunities for men and women. http://lex.uz/docs/4494873

6. Presidential Decree No. UP-5270 of 1 December 2017 on measures to radically improve the system of State support for persons with disabilities. http://lex.uz/docs/3436196.

7. AleksandrovaO.V.Differential psychological factors of experience and copying of adult behavior in a difficult life situation: Dis... Candidate of Psychology: 19.00.13: St. Petersburg, 2017. - P. 245.

8. Annenkova E.A. Personal determinants of the assessment of difficult life events by boys and girls and their coping strategies: Abstract: 19.00.01: Rostov-on-Don, 2010. P.23. 